\title{
ЕТНОДЕМОГРАФІЧНА СИТУАЦІЯ У НАДДНІПРЯНСЬКІЙ УКРАЇНІ В КІНЦІ ХІХ - НА ПОЧАТКУ ХХ СТОЛІТТЯ
}

Анотація: У статті аналізується етнодемографічна ситуація в Наддніпрянській Україні кіния XIX - початку XXст. Вказана проблема $\epsilon$ актуальною, оскільки населення України $\epsilon$ поліетнічним. Впродовж століть на території Наддніпрянської України поруч з україниями мешкали й представники інших національностей, найчисленнішими з яких були росіяни, євреї, поляки та німщі. Їхня поява на українських землях зумовлена різними причинами: економічними, політичними, військовими, конфесійними. Насамперед, слід виділити сприятливе геополітичне становище та родючі землі, що приваблювали селян із-за кордону.

Регіональне розміщення національних меншин в Україні було нерівномірним. Зокрема, найбільші з них зосередилися так: росіяни - переважно у південному та північно-східному регіонах України, євреї та поляки - у Волинській, Подільській, Київській і Херсонській губерніях, німщі - на південноукраїнських землях. У містах зі згаданих етносів найбільще були представлені євреї та росіяни.

Ключові слова: поліетнічність, національні меншини, Наддніпрянська Украӥна, росіяни, поляки, євреї, німщі

Населення України $є$ поліетнічним. Поруч 3 українцями тут проживають представники інших національностей, які відрізняються походженням, мовою, культурою, традиціями, звичаями, конфесійною належністю, рівнем політичного розвитку, ступенем етнічної самоорганізації. Їхня частка у складі населення України, як і їхн чисельність, ніколи не були стабільними. Процес формування поліетнічного населення Наддніпрянської України в кінці XIX - на початку XX ст. є важливим для розуміння процесів, що відбувалися в добу Української революції (1917-1921 рр.) та мають вплив на сучасне етнополітичне становище нашої держави.

Важливий внесок у вивчення причин переселення й основних тенденцій зростання чисельності та розселення найбільших національних меншин України, з'ясування етнічного співвідношення мешканців міст і сіл зробили А. Кicce, I. Міронова², С. Чорний ${ }^{3}$. Низка науковців присвятили свої праці дослідженню означеної проблеми через призму російської, єврейської, польської, німецької й інших національних меншин України. Серед останніх

\footnotetext{
"Матвієнко Людмила Володимирівна - кандидат історичних наук, доцент кафедри соціально-гуманітарних дисциплін Національного університету кораблебудування імені адмірала Макарова (Миколаїв, Україна); ORCID: https://orcid.org/0000-0001-8932-5757; e-mail: matvienko_nyk@ukr.net

${ }^{1}$ Kiсcе A.I. Міжетнічна взаємодія в Україні: етноісторичні традиції // Наукові праці. Серія: Політологія. 2004. Т. 34. Вип. 21. С. 99-106.

${ }^{2}$ Міронова I.C. Національні меншини України. Миколаїв-Одеса: ТОВ ВіД, 2006. 305 с.

${ }^{3}$ Чорний C. Національний склад населення України в XX сторіччі: довід. Київ: Картограф, 2001. 88 с.
} 
слід виділити роботи О. Калакури ${ }^{4}$, М. Козирєвої ${ }^{5}$, І. Лісевич ${ }^{6}$.

Мета статті - проаналізувати етнодемографічну ситуацію на території Наддніпрянської України в кінці XIX - на початку XX ст.

Заселення українських земель представниками національних меншин було зумовлене різними причинами. Насамперед - це сприятливе геополітичне становище, наявність родючих земель, що приваблювали іноземних селян-землеробів, тривале перебування України в складі інших держав, політика урядів, спрямована на заселення ї̈ території іноземцями. На кількісному складі та розміщенні поліетнічного населення, його гетерогенності та дисперсності суттєво позначилися міграційні процеси ${ }^{7}$, які особливо посилилися в XIX - на початку XX ст. У той період землі України (в її нинішніх кордонах), зберігаючи природно-географічну цілісність, залишалися в адміністративному, етнополітичному та культурно-духовному відношеннях розділеними між двома імперіями. Основна їхня частина - близько 80\% (Лівобережжя, весь Південь і Крим, Слобожанщина і Правобережжя) - перебувала у складі Російської монархії, решта (Східна Галичина, частина Західної Волині, Північна Буковина та Закарпаття) $)^{8}$ - у складі Австро-Угорщини.

Прагнучи ліквідувати українську автономію, позбутися корінних мешканців і мати покірних вірнопідданих, російський царат проводив насильницьке переселення народів. У результаті запорозьке козацтво опинилося за Дунаєм, кримські греки та вірмени - на північних берегах Азовського моря і Дону, а ногайці та десятки тисяч татар втекли у турецькі володіння. Проте Російська імперія була не в змозі освоїти своїми силами спустілий край і новоприєднані степові простори, оскільки цьому заважало кріпосне право ${ }^{9}$. Було вирішено запросити колоністів із-за кордону.

Правову основу іноземної колонізації започаткували маніфести російської імператриці Катерини II у 1762, 1763 та 1764 рр. Переселенцям гарантувалися свобода релігії та звичаїв, самоврядування, звільнення від рекрутчини, виконання повинностей і сплати податків на визначений термін, надання достатньої кількості земель, асигнування 3 державної скарбниці для початку господарювання. Типовими причинами, які спонукали переселенців покинути обжиті землі, були такі: численні війни, які погіршували становище населення; відсутність вільних земель на батьківщині; релігійні утиски в Західній Європі окремих протестантських течій ${ }^{10}$.

\footnotetext{
${ }^{4}$ Калакура О.Я. Поляки в етнополітичних процесах на землях України у XX столітті. Київ: Знання України, 2007. $508 \mathrm{c}$.

${ }^{5}$ Козирєва М. Адміністративно-територіальні перетворення німецьких районів півдня України в 20-30 pp. XX століття // Німецькі поселенці в Україні: Історія та сьогодення. Київ-Миколаїв: Вид-во МДгу ім. П. Могили, 2006. C. 324-331.

${ }^{6}$ Лісевич I. Польська національна меншина в Наддніпрянській Україні (1864-1917 pр.) // Український історичний журнал. 1997. № 2. С. 43-54.

${ }^{7}$ Національні меншини України у XX столітті: політико-правовий аспект / М. Панчук, В. Войналович, О. Галенко та ін.; редкол.: І. Курас (голов. ред.) та ін.; НАН України; Ін-т політ. і етнонац. досліджень. Київ, 2000. C. 15 .

${ }^{8}$ Ігнатова Л., Рамазанов Ш. Національне питання в програмах українських політичних партій Наддніпрянщини на початку XX ст. // Університет. 2008. № 6. С. 23.

${ }^{9}$ Плескал-Зебольд 3. Немецкие колонисты на Одесчине // Німецькі поселенці в Україні: Історія та сьогодення. Київ-Миколаїв: Вид-во МДгУ ім. П. Могили, 2006. С. 215-216.

${ }^{10}$ Козирєва М. Адміністративно-територіальні перетворення німецьких районів... С. 324.
} 
Упродовж XVIII - на початку XIX ст. на українських землях постала низка військових поселень іммігрантів із країн, що потерпали від турецької агресії. Військові поселенці належали до селянського стану, але мали деякі пільги. Таким чином російський уряд вирішував важливе стратегічне завдання: створення укріплених районів, які могли захистити південні рубежі імперії та стати плацдармом для подальшого просування на південь.

Другим урядовим завданням, підпорядкованим першому, було господарське освоєння південноукраїнських земель. Для цього у регіоні сформували військові округи Новосербія, Слов'яносербія, Бузьке козацьке військо.

На 80-ті рр. XVIII ст. припадає початок іноземної землеробської колонізації Півдня України, насамперед Катеринославської, Херсонської і Таврійської губерній. 3 того часу, як зазначають дослідники, вже великі організовані громади іноземців почали переселятися у малозаселені й економічно відсталі степи для їх культурного освоєння.

Важливою проблемою дослідження є визначення чисельності, складу та суспільного становища національних меншин як загалом в Україні, так і в окремих їі регіонах. Для уявлення про кількісні характеристики етнічного складу населення України на початок Української революції варто звернутися до статистичних даних того періоду. Насамперед йдеться про перший загальний перепис населення Російської імперії 1897 р. Слушною є думка В. Кубійовича про те, що тодішня статистика має чимало хиб, але інших даних не iснує $\epsilon^{11}$, і саме вони залишаються відправною точкою для сьогоднішніх досліджень.

На початку XX ст. все населення України складалося з понад 20 етнічних груп, розселених переважно компактно. Відповідно до даних М.Шаповала, на етнічних українських землях, що охоплювали територію $739161 \mathrm{kм}^{2}$, у той час проживало 46012000 осіб. Серед них: 32662000 українців (71\% від усього населення), 5376800 росіян (11,7\%), 3795760 євреїв (8,2\%), 2079500 поляків (4,5\%), 871270 німців (1,9\%), 435540 волохів $(0,9 \%), 104780$ греків (0,2\%), 39400 вірмен $\left(0,1 \%{ }^{12}\right)$. Трохи більше, ніж $1 \%$, становили представники інших національностей.

Таким чином, найчисленнішою національною меншиною в Україні були росіяни. Їхні найбільші етнічні масиви на сучасній території України виникли приблизно у XV-XVII ст. у Слобідській Україні, де «службово-ратні люди» отримували приміські слободи ${ }^{13}$. Перебування Чернігово-Сіверщини в складі Московської держави у XVI - на початку XVII ст. сприяло появі на цій території російських поміщиків та іншої московської людності.

3 другої половини XVII ст. помітно стала зростати міграція росіян передусім на Лівобережжя, в Причорномор'я і Крим, що було зумовлено збільшенням військових залог після Березневих статей 1654 р. і стихійною втечею старовірів. Як наслідок, якщо у 1678 р. у південному регіоні зафіксовано 27 тис. росіян, то в 1719 р. - 72 тисячі. На Лівобережжі в той період налічувалося 40 тис. росіян. Після ліквідації Гетьманщини російська експансія набула характеру належно спланованої довготривалої політики. Упродовж першої половини XIX ст. чисельність росіян в Україні зросла більш ніж на 1 млн. осіб і досягла у

\footnotetext{
${ }^{11}$ Енциклопедія українознавства. Загальна частина: у 3 т. Т. 1 / голов. ред.: проф., д-р В. Кубійович, проф., д-р

3. Кузеля. [Репринт. відтворення вид. 1949 р.]. Київ, 1994. С. 156.

${ }^{12}$ Шаповал М. Велика революція і українська визвольна програма. Прага: Вільна спілка, 1927. С. 6-7.

${ }^{13}$ Національні меншини України у XX столітті: політико-правовий аспект... С. 12.
} 
1858 р. 1 млн. 407 тис. осіб ${ }^{14}$.

Особливо інтенсивно зростала чисельність російського населення із зародженням капіталістичних відносин. Регіоном активного промислового розвитку, куди воно мігрувало, став Донбас. Згідно з Всеросійським переписом населення 1897 р., там проживало 687,3 тис. осіб, у т. ч. 55,2\% українців і 26,2\% росіян ${ }^{15}$. Загалом у Наддніпрянській Україні тоді нараховувалося 2 млн. 473 тис. (10,4\%) росіян, на території у сучасних межах від $2,5(8,8 \%)$ до 2,8 млн. $(10,5 \%)^{16}$. Більшість із них проживала у містах Півдня та Слобожанщини.

За станом на 1916 р. в українських губерніях Російської імперії із загальної кількості населення, яка дорівнювала 35470 тис. осіб, росіяни становили близько 3,5 млн. (9,9\%) ${ }^{17}$.

Початок присутності євреїв на українських теренах сягає дохристиянських часів, коли вони прибули до Криму та на Східне узбережжя Чорного моря. Звідти єврейство розселялося в долинах р. Волги і Дону, де у VII-X ст. існувала Хозарська держава. Після поразки останньої у 964 р. від військ Великого князя київського Святослава єврейське населення розійшлося по Криму, Кавказу, а частина потрапила до Русі-України. Найбільше євреїв проживало у Києві. Занепад княжої держави на українських землях збігся за часом із переслідуванням євреїв на Заході. Тому вони змушені були втікати до Східної Європи, переважно у Польщу, а звідти - до України ${ }^{18}$.

Після загарбання Російською імперією більшості українських земель останні опинилися у складі т. зв. смуги осілості (1791-1917 рр.) - території компактного проживання євреїв у Російській імперії, визначеній царським урядом для запобігання проникнення їх у великоруські губернії та захисту російського підприємництва від єврейської конкуренції. 3 9 українських губерній до неї увійшли 8: Волинська, Катеринославська, Київська, Подільська, Полтавська, Таврійська, Херсонська, Чернігівська ${ }^{19}$.

Наприкінці XVIII ст. посилилась єврейська колонізація Півдня і Причорномор'я України. 3 другої половини ХІХ ст. єврейський елемент став домінуючим у низці південних міст і містечок. Після внесення деяких змін у законодавство в 1849 p. $^{20}$ євреї розселилися у південно-східній частині України.

У ХІХ ст. чисельність єврейства істотно зросла. Якщо впродовж 1820-1880 pр. загальна кількість населення Російській імперії збільшилася на 87\%, то єврейська частка на 150\%. Відповідно до Всеросійського перепису населення 1897 р., в Наддніпрянській Україні проживало понад 1942 тис. євреїв $(8,17 \%)^{21}$. Дещо інші дані за означений період подає «Енциклопедія українознавства»: 2245 тис. євреїв, або 7,4\% ${ }^{22}$ щодо населення краю загалом.

\footnotetext{
${ }^{14}$ Міронова І.С. Національні меншини України... С. 156.

15 Лаврів П. Національна свідомість робітництва на Донеччині // Сучасність. 1992. № 6. С. 104.

${ }^{16}$ Кравиів Б., Кубійович В. Росіяни на Україні [У 19 в. і на поч. 20 в. до 1917] // Енциклопедія українознавства. Словникова частина: в 10 т. Т. 7 / голов. ред. В. Кубійович; Наук. т-во ім. Т. Шевченка. [Репринт. відтворення вид. 1955-1984 рр.]. Париж-Нью-Йорк-Львів: НТШ, 1998. С. 2614.

${ }^{17}$ Національні меншини України у ХХ столітті: політико-правовий аспект... С. 11.

${ }^{18}$ Шестопал М. Євреї на Україні; упоряд. і передм. В. Яременка. Київ: МАУП, 2002. С. 40.

${ }^{19}$ Малий словник історії України / В. Смолій (відп. ред.). Київ: Либідь, 1997. С. 369.

${ }^{20}$ Національні меншини України у ХХ столітті: політико-правовий аспект... С. 13.

${ }^{21}$ Чорний С. Національний склад населення України в ХХ сторіччі... С. 36-37.

${ }^{22}$ P.М. Жиди // Енциклопедія українознавства. Словникова частина: в 10 т. Т. 2 / голов. ред. В. Кубійович; Наук. т-во ім. Т. Шевченка. [Репринт. вид. 1955-1984 рр.]. Париж-Нью-Йорк-Львів: НТШ, 1993. С. 675.
} 
Третьою за чисельністю групою поліетнічного населення України були поляки. Кардинально змінився характер переселенського процесу з польських земель наприкінці XVIII ст., коли було ліквідовано й українську, і польську державність: із 1795 до 1909 рр. частка польського населення України знизилася з 10 до 6,4\%. На Сході міграція поляків здебілышого була спрямована в українське Причорномор'я, де впродовж XIX ст. їхня питома вага зросла з 0,1-0,3 до 2\%.

3 прискоренням розвитку капіталізму в Російській імперії активізувався приплив капіталу та робочої сили з Польщі у райони Середнього Придніпров'я та Донбасу. Загалом, згідно з розрахунками І.Лісевича, на початку 60-х рр. ХІХ ст. польське населення у Наддніпрянській Україні становило близько 480-485 тис. осіб ${ }^{23}$. Проте за Першим переписом населення Російської імперії 1897 р. в Україні зафіксовано зменшення кількості поляків до 391,2 тис. (1,65\%) $)^{24}$. Деякі дослідники вважають цю цифру заниженою та мотивують їі побоюванням частини населення оприлюднювати своє походження ${ }^{25}$.

Зокрема, О. Калакура на основі даних того самого перепису населення підрахував, що у Наддніпрянській Україні мешкало понад 476 тис. осіб, які визнавали рідною польську мову $^{26}$. До початку Першої світової війни кількість поляків в Україні досягнула близько 600 тис. осіб (майже 2,5\%). Однак, на 1 січня 1916 р. у «Статистичному щорічнику» подано цифру більш ніж на чверть меншу за попередню - 445 тис. ${ }^{27}$

Перші писемні відомості про німецьких поселенців в Україні датовані кінцем X ст. Їх заохочували привілеями галицько-волинські князі для надання допомоги у відбудові зруйнованих міст ${ }^{28}$. У литовсько-польську добу німецькі колоністи з'явилися на Поділлі, а в XVI - першій половині XVII ст. - у Наддніпрянщині та Лівобережній Україні.

3 останньої третини XVIII ст. рух німецьких колоністів набув системного характеру. Перші шість їхніх компактних поселень було засновано в 1767 р. поблизу Бахмачу на Чернігівщині. Після знищення Запорозької Січі іï землі у 1789-1790 pp. заселили представниками менонітської релігійної громади.

На початку XIX ст. вихідці з Німеччини прибули на Південь України, переважно в Таврійську, Катеринославську, Херсонську губернії, а згодом - до Бессарабії.

Темпи зростання німецьких колоній, зумовлені пільговими умовами, наданими царським урядом, були вражаючими. Так, якщо у 20-ті рр. XIX ст. у Херсонській губернії було 40 поселень, Таврійській - 50, Катеринославській - 26, то у 1915 р. відповідно ця кількість досягла 182, 329 та 233 колоній ${ }^{29}$. В 1914 р. у чотирьох південних губерніях налічувалося 966 колоній ${ }^{30}$.

\footnotetext{
${ }_{23}^{3}$ Лісевич I. Польська національна меншина в Наддніпрянській Україні (1864-1917 рр.)... С. 44.

${ }^{24}$ Чорний C. Національний склад населення України в XX сторіччі... С. 37.

${ }^{25}$ Лісевич I. Польська національна меншина в Наддніпрянській Україні (1864-1917 рр.)... С. 45.

${ }^{26}$ Калакура О.Я. Поляки в етнополітичних процесах на землях України у XX столітті. Київ: Знання України, 2007. C. 102.

${ }^{27}$ Національні меншини України у XX столітті: політико-правовий аспект... С. 12.

${ }^{28}$ P.М. Німці на Україні // Енциклопедія українознавства. Словникова частина: в 10 т. Т. 5 / голов. ред. В. Кубійович; Наук. т-во ім. Т. Шевченка. [Репринт. відтворення вид. 1955-1984 рр.]. Париж-Нью-ЙоркЛьвів: НТШ, 1996. С. 1770.

${ }^{29}$ Національні меншини України у XX столітті: політико-правовий аспект... С. 14.

${ }^{30}$ P.М. Німці на Україні... С. 1771-1772.
} 
Зі зростанням кількості колоній збільшувалась і чисельність населення: за перші 20 років - у 8 разів, а до 1857 р. - у 25 разів, досягнувши майже 140 тис. осіб. Питома вага німецьких переселенців підвищувалася в усіх районах їхнього розселення, однак у різних пропорціях. Упродовж 1815-1857 рр. їхня частка у Таврійській губернії збільшилася втричі з 2,42 до 6,32\%; у Херсонській - у півтора рази, з 3,54 до 4,52\%; у Бессарабії - 3 2,13 до 2,3\%; Катеринославській губ. - 3 0,6 до 2,28\% ${ }^{31}$.

Якщо у 1897 р., відповідно до перепису населення, на Півдні України проживало 377,8 тис. німців, у т. ч. в Херсонській губернії - 123,5 тис. (4,52\%), Катеринославській майже 81 тис. (3,83\%), Таврійській - понад 78 тис. осіб (5,4\%), то до 1911 р., згідно $з$ даними німецьких джерел, їхня кількість зросла до 489 тисяч. У 1914 р. в Південній Україні (без Кубані) проживало 467 тис. осіб ${ }^{32}$. Останні дві цифри викликають певні сумніви, оскільки незрозумілим є скорочення кількості німецького населення за три роки на 22 тис. осіб.

Порівняно значними за кількістю населення серед етнічних меншин на українських землях були румуни та молдовани, татари, греки, болгари, угорці, білоруси, чехи, вірмени й ін. Чисельність кожної з цих груп коливалась у межах від декількох сотень до декількох десятків тисяч осіб. Вони відігравали певну роль у житті регіону та створювали особливий етнічний колорит.

Дослідники вказують на нерівномірність розміщення національних меншин в Україні та пояснюють це передусім історичними умовами їхнього комплектування ${ }^{33}$. Так, однією з особливостей міграції росіян в Україну було те, що основний потік переселенців спрямовувався у порівняно малозаселені південні та східні райони сучасної України Причорномор'я, Приазов'я та Слобожанщину.

За даними перепису населення Російської імперії, у 1897 р. в Україні мешкало 5,25\% росіян $^{34}$. Найбільшою була їхня частка серед населення північно-східного - 19,56\% (Чернігівської губернії - 21,58\%, Харківської - 17,69\%) та південного регіонів України - 18,23\% (Таврійської - 27,94\%, Херсонської - 21,05\%, Катеринославської - 17,27\%, Бессарабської губерній - 8,05\%). Найменший відсоток російського населення припадав на Полтавську губернію - 3,28\% ${ }^{35}$. Присутність росіян на інших українських землях була незначною.

Єврейська меншина у Наддніпрянській Україні становила в 1897 р. понад 42\% євреїв Російської імперії ${ }^{36}$ Основна їхня маса проживала в смузі осілості. 3 українських губерній найбільший відсоток євреїв визначено у Волинській - 13,21\%, Подільській 12,24\%, Київській - 12,1\%, Херсонській - 11,8\%, Бессарабській губ. - 11,79\%. Найменше єврейського населення мали Чернігівська - 4,93\%, Катеринославська - 4,69\%, Полтавська

\footnotetext{
${ }^{31}$ Kiсcе А.І. Міжетнічна взаємодія в Україні: етноісторичні традиції... С. 105.

${ }^{32}$ P.М. Німці на Україні... С. 1770.

${ }^{33}$ Національні меншини України у ХХ столітті: політико-правовий аспект... С. 12, 49.

${ }^{34}$ Распределение населения по главнейшим сословиям, вероисповеданиям, родному языку и по некоторым занятиям: краткие общие сведения по Империи / предисл. Н. Тройницкий. Санкт-Петербург: Паровая типолитография Н.Л. Ныркина, 1905. С. 4-6.

${ }^{35}$ Ibid. C. $4-5$.

${ }^{36}$ Общий свод по Империи результатов разработки данных первой всеобщей переписи населения, произведенной 28 января 1897 года. Т. 2 / предисл. Н. Тройницкий. Санкт-Петербург, 1905. LX. C. XVI; Распределение населения по главнейшим сословиям, вероисповеданиям, родному языку и по некоторым занятиям: краткие общие сведения по Империи... С. 5.
} 
- 3,97\%, Таврійська - 3,83\% і Харківська губ. - 0,51\% ${ }^{37}$.

На території Наддніпрянської України найбільший відсоток поляків у 1897 р. проживав у Волинській губ. - 6,16\%, Подільській - 2,29\%, Київській - 1,93\%, Херсонській 1,13\%. На інших територіях їх було менше 1\%. До 1916 р., згідно 3 даними «Статистичного щорічника» ${ }^{38}$, це співвідношення не змінилося.

Німецька національна меншина становила в 1897 р. 30,8\% від усіх німців Російської імперії. Найбільшою була їхня частка серед населення Волинської губернії - 5,73\%, Таврійської - 5,4\%, Херсонської - 4,52\%, Катеринославської - 3,83\%, Бессарабської 3,11\%. В інших місцевостях німецького населення було менше $1 \%{ }^{39}$.

Окрім регіональних відмінностей поселення, етнічні суб'єкти України помітно різнилися й тим, що одні з них проживали здебільшого у містах і містечках, а інші - в селах. Статистика засвідчує, що відсоток українців у великих містах, за винятком Полтави і Чернігова, не був переважаючим.

Так, наприклад, у 1917 р. у Києві з 467,6 тис. душ населення українці становили лише 76,6 тис. осіб (16\%). Така тенденція спостерігалася в Одесі, Харкові, Катеринославі, містах Донбасу ${ }^{40}$ та в інших промислових центрах.

Згідно з переписом 1897 р., майже цілковито (94,15\%) в містах і містечках Російської імперії були згруповані євреї, які становили 15,64\% від представників міщанського стану ${ }^{41}$. Проте в Україні ці показники були дещо меншими - лише 66,2\% наддніпрянських євреїв проживали у містах. Частка єврейського міського населення становила: у Волинській губ. - 50,8\%, Подільській - близько половини, Бессарабській $37 \%$, Херсонській і Київській - близько $30 \%{ }^{42}$.

У низці міст євреї становили більшість населення. Зокрема, на Волині напередодні Першої світової війни у м. Луцьку і Володимирі-Волинському їхня частка дорівнювала $60 \%$, у Любомлі - 74\%, у Рожищі - 83\%. Неформальним центром євреїв краю був Бердичів, де вони становили 78\%. У Києві чисельність єврейства в 1917 р. дорівнювала 87200 осіб, або майже 19\%, в Умані - 58\%, Білій Церкві - 53\% міського населення ${ }^{43}$.

Значну частину представників серед міського населення України мали росіяни 42,3\% від їхньої загальної кількості. Серед усіх міщан частка російського населення становила 33,7\% (українського - 32,5\%) ${ }^{44}$. Концентрація у містах, переважно у великих, була однією з особливостей розселення росіян в Україні.

\footnotetext{
${ }^{37}$ Общий свод по Империи результатов разработки данных первой всеобщей переписи населения, произведенной 28 января 1897 года. Т. 2... С. XVII.

${ }^{38}$ Калакура О.Я. Поляки в етнополітичних процесах на землях України у XX столітті... С. 102.

${ }^{39}$ Общий свод по Империи результатов разработки данных первой всеобщей переписи населения, произведенной 28 января 1897 года. Т. 2... С. XII; Распределение населения по главнейшим сословиям, вероисповеданиям, родному языку и по некоторым занятиям: краткие общие сведения по Империи... С. 4.

${ }^{40}$ Національні меншини України у XX столітті: політико-правовий аспект... С. 70.

${ }^{41}$ Общий свод по Империи результатов разработки данных первой всеобщей переписи населения, произведенной 28 января 1897 года. Т. 2... C. XVI, LVIII.

${ }^{42}$ Ibid. C. XVII.

${ }^{43}$ P.М. Жиди... С. 675.

${ }^{44}$ Кравиів Б., Кубійович В. Росіяни на Україні [У 19 в. і на поч. 20 в. до 1917] // Енциклопедія українознавства. Словникова частина: в 10 т. Т. 7 / голов. ред. В. Кубійович; Наук. т-во ім. Т. Шевченка. [Репринт. відтворення вид. 1955-1984 рр.]. Париж-Нью-Йорк-Львів: НТШ, 1998. С. 2614.
} 
Найбільшими їхніми міськими зосередженнями у 1897 р. були: Одеса - 198,2 тис. (48,2\% від населення міста загалом), Київ - 134,3 тис. (54,4\%), Харків - 109,9 тис. (63,0\%), Миколаїв - 61,0 тис. (66,3\%), Катеринослав - 47,1 тис. (41,8\%), Херсон - 27,9 тис. (47,9\%), Житомир - 16,9 тис. (25,6\%), Полтава - 11,0 тис. $(20,6 \%)^{45} .3$ одного боку, така ситуація була зумовлена індустріалізацією та пов'язаним із нею напливом до міст пролетарського елементу з Росії. 3 іншого - з моменту втягнення українських земель в імперську орбіту міста втрачали національне обличчя, перетворюючись в адміністративні та військові центри, де домінували росіяни зі своєю мовою та культурою.

Переважна більшість німецького населення мешкала у сільській місцевості. Однак, якщо загалом в європейській частині Російської імперії в містах проживала чверть (23,3\%) німців $^{46}$, яких найбільше було в Одесі (1897 р. - 10,2 тис. (2,5\%) осіб), то в Наддніпрянщині перебувала лише десята їхня частина ${ }^{47}$. Таку диспропорцію можна пояснити лише високою продуктивністю українських земель.

В Наддніпрянській Україні відсоток міщан-поляків, згідно з переписом 1897 р., дорівнював 15,28\%. Так, якщо їхня частка серед населення Волинської губ. становила 6,2\%, то в містах цієї губернії - 7,6\% ${ }^{48}$.

Висновки. Упродовж століть Наддніпрянська Україна була краєм, який приваблював значні маси іноземного населення. Поруч з українцями на цій території мешкали й представники інших національностей, найчисленнішими з яких були росіяни, євреї, поляки та німці. Їхня поява на українських землях зумовлена різними причинами: економічними, політичними, військовими, конфесійними. Насамперед, слід виокремити сприятливе геополітичне становище, зокрема, місце у міжнародних торговельних зв'язках, родючі землі, що приваблювали селян із-за кордону.

Безпосереднім наслідком імперської колонізаційної політики стало зростання поліетнічності тих регіонів, щодо яких вона була спрямована. Регіональне розміщення національних меншин в Україні було нерівномірним. Зокрема, найбільші 3 них зосередилися так: росіяни - переважно у південному та північно-східному регіонах України, євреї і поляки - у Волинській, Подільській, Київській і Херсонській губерніях, німці - на південноукраїнських землях. У містах зі згаданих етносів найбільше були представлені євреї та росіяни.

\footnotetext{
${ }^{45}$ ЛазаровичM. Російська національна меншина України у XIX - на початку XX століття: соціальноекономічний вимір // Українська наука: минуле, сучасне, майбутнє. 2014. Вип. 19. Ч. 2. С. 88.

${ }^{46}$ Общий свод по Империи результатов разработки данных первой всеобщей переписи населения, произведенной 28 января 1897 года. Т. 2... С. ХІІ.

${ }^{47}$ Р.М. Німці на Україні... С. 1772.

${ }^{48}$ Общий свод по Империи результатов разработки данных первой всеобщей переписи населения, произведенной 28 января 1897 года. T. 2... C. LVIII.
} 


\title{
Liudmyla Matvienko
}

\section{The ethnodemographic situation in Dnieper Ukraine at the end of the XIX - early XX centuries}

\begin{abstract}
The article analyzes the ethno demographic situation in Dnieper Ukraine at the end of the nineteenth and the beginning of the twentieth century. The indicated problem is relevant, as the population of Ukraine is polyethnic. For centuries, representatives of other nationalities, who differ in origin, language, culture, traditions, customs, confessional affiliation, level of political development and degree of ethnic self-organization have also lived on the territory of Dnieper Ukraine next to Ukrainians. The most numerous of which were Russians, Jews, Poles and Germans. Their appearance on Ukrainian lands is due to various reasons: economic, political, military and confessional. First of all, it is necessary to highlight the favorable geopolitical position, in particular, the place in international trade relations, fertile land, mainly in the southern and north-eastern regions of Ukraine. The regional distribution of national minorities in Ukraine was uneven. In particular, the largest of them were concentrated like this: Russians - mainly in the southern and north-eastern regions of Ukraine.

An imminent consequence of the Imperial colonization policy was the growth of the polyethnicity of the regions of which it was directed. In the 80s of the eighteenth century the process of foreign agricultural colonization of the South of Ukraine began, foremost the provinces of Katerynoslav, Kherson and Tauride.

At the beginning of the twentieth century, the entire population of Ukraine consisted of more than 20 ethnic groups, settled mainly compactly.

The regional placement of the national minorities in Ukraine was uneven. In particular, the largest of them were concentrated thus: Russians - mainly in the southern and northeastern regions of Ukraine, Jews and Poles - in the Volyn, Podolsk, Kyiv, and Kherson provinces, Germans - in the southern Ukrainian lands. In the cities of the mentioned ethnic groups, Jews and Russians were most represented.
\end{abstract}

Keywords: polyetchnicity, national minorities, Dnieper Ukraine, Russians, Poles, Jews, Germans 